\title{
Editor's Perspective
}

\author{
Denise L. Rode
}

As my staff and I put the finishing touches on this issue of the Journal of College Orientation and Transition, I have new-found respect for the work my predecessors did to lay the foundation for this publication.

Very few current members of the National Orientation Directors Association will remember Volume 1, No. 1 of the NODA Journal, which was published in Fall 1982. Editor Victor S. Zarzycki of the Philadelphia College of Art introduced the journal as containing "articles written for the higher education professional who is responsible for the development, implementation, and assessment of programs directed toward the orientation of students to the college/university environment" (p. 1).

Types of submissions considered at that time were dialogues, poems, and full-length and "in the field" articles. A sampling of titles from that journal include "Student Leaders-Key to Success" and "Perry's Theory: A Model for Paraprofessional Selection and Training" - an indication that even in the early days of the profession, there was a keen interest in the development of student orientation leaders.

According to Jacobs (1997), "NODA's journal. . .had a sporadic history with varying levels of support for the endeavor. With a shaky financial structure and a lack of submissions, it was logical to put. . publication efforts on hold in 1986" (p. 5).

It was not until 1996 that the Association saw fit to relaunch the Journal under new leadership and a new title. Under the able editorship of Bonita C. Jacobs of the University of North Texas, and a team of respected associate editors with strong experience in the field of Orientation, the Journal of College Orientation and Transition was revitalized and has been continuously published since Fall 1997. Jacobs wrote at the time, "It was obvious that we [NODA] had both the need for scholarship and the membership capable of producing state-of-the-art professional articles" (p. 5).

Indeed, the reestablishment of the Journal was "a hallmark of the growth, struggles, and success of the National Orientation Directors Association" (Jacobs, 1997, p. 5). Has the Journal made a difference for NODA and its members? Most certainly, yes! With the guidance of Jacobs and her successor, Michael T. Miller of the University of Arkansas, the Journal has flourished and consistently has published scholarly work. As our Association has matured, so has the Journal in its size, scope, and standards.

As the landscape of orientation programs, transition services, and the first-year experience movement continues to evolve and expand, so too will the Journal. As the incoming editor of this publication, I am committed to building on the solid foundation laid by my predecessors, with the help of six capable associate editors. 
Former editor Jacobs described the process of editing a journal as being "like nurturing a child. Those. . .who are parents understand the joys, frustrations, worries, care, relief, doubt, anxieties, and thrills of watching a personality emerge and a child become its own being. .." (p. 5). And so it is with that same mix of emotions that this editor begins her course with The Journal of College Orientation and Transition. I invite you, as a NODA member, to be part of the Journal - to read and react, to write and contribute, to provide your thoughts of future directions for this growing "child."

\section{References}

Jacobs, B. C. (1997). The case for scholarship. The Journal of College Orientation and Transistion, 5(1), 5-6.

Zarzycki, V. S. (Ed.) (1982). NODA Journal 1(1). 